\title{
The Street-Wise University: The Amsterdam Knowledge Mile as an Intermediary and Place-Making Concept
}

\author{
Willem van Winden *, Iris Hagemans and Patricia van Hemert \\ Centre for Applied Research on Business and Economics, Faculty of Business and Economics, \\ Amsterdam University of Applied Sciences, 1000 BA Amsterdam, The Netherlands \\ * Correspondence: w.van.winden@hva.nl; Tel.: +31-(0)6-1156055
}

Received: 24 June 2019; Accepted: 29 July 2019; Published: 31 July 2019

check for updates

\begin{abstract}
Universities have become more engaged or entrepreneurial, forging deeper relations with society beyond the economic sphere. To foster, structure, and institutionalize a broader spectrum of engagement, new types of intermediary organizations are created, going beyond the "standard" technology transfer offices, incubators, and science parks. This paper conceptualizes the role of such new-style intermediaries as facilitator, enabler, and co-shaper of university-society interaction, making a distinction between the roles of facilitation, configuration, and brokering. As a case study, the paper presents the Knowledge Mile in Amsterdam as a novel form of hyper-local engagement of a university with its urban surroundings that connects the challenges of companies and organisations in the street to a broad range of educational and research activities of the university, as well as to rebrand the street.
\end{abstract}

Keywords: engaged university; entrepreneurial university; living lab; intermediation; higher education

\section{Introduction}

In the last decades, universities have become more engaged or entrepreneurial, forging deeper relations with society. Whereas the focus used to be on economic aspects (spin-offs, patenting/licensing, science park development), engagement is broadening and deepening. A growing number of universities present themselves as player or partner in solving societal challenges such as ageing, climate change, and energy transition, triggering more integrated and interdisciplinary approaches and links with a broader set of societal actors. Also, engagement practices are deepening where research and educational programmes are becoming more interwoven with society through action research, service learning, and problem-based learning, which rely on real-world case work in which students and academics interact and co-create with governments, companies, and other organisations.

It has become common for universities to have dedicated intermediary departments or organisations to systematically foster interaction with society, in the form of technology transfer offices or incubators, helping academics to valorize research findings, forge links with companies, or create startups. These types of intermediaries predominantly focus on economic aspects, and are described and analysed in-depth in the literature. Much less documented are new types of intermediaries that are being set up to foster and support different and broader types of engagement that go beyond the economic realm and are more linked to the ambition of universities to address societal challenges and adopt action research or new, more interactive educational concepts.

From this perspective, in this paper, we address the research question of how intermediary organizations play a role in mediating new, broader types of university-society engagement that surpass or transcend the economic realm. We explore the case of the Knowledge Mile (KM) in 
Amsterdam, as a novel type of intermediary between university and society, surpassing "traditional" economically-inspired university knowledge transfer activities to include community formation, demand articulation, co-creation, and place-making with players in the urban neighbourhood and local government. We will describe how the Knowledge Mile has resulted in new collaborations between academics/students and urban stakeholders; we also discuss the, at times, problematic institutionalisation of the KM into a business investment zone, and wider implications for university engagement.

This paper is organised as follows. First, we sketch the broader context of universities becoming more "entrepreneurial" or engaged with society, fostering new types of functional and spatial relations and intermediation. We describe the general tendency of universities moving from a primacy of economic engagement (focused on the valorisation of academic knowledge and research via patenting, licensing, spin-offs, contract research) into more comprehensive forms of engagement. Next, we conceptualise the role of intermediary organisations in mediating the university-society connection, drawing from the literature on innovation intermediaries, making a distinction between three roles of intermediaries: facilitation, configuring, and brokering. As a case, we present the Knowledge Mile as a novel type of intermediary. We describe the rationale for the development of the KM (from the background of the Dutch university system and the strategy of Amsterdam University of Applied Sciences (AUAS)), how the Knowledge Mile was developed, and elaborate with some examples of how it organised the community and fostered collaborative education and research projects. The paper ends with conclusions and reflections on the role of intermediation in university-society linkages.

\section{Context and Frame of Analysis}

Many studies have documented and discussed the evolution of university-society relations (Clark 1998; McIlrath et al. 2012; Benneworth et al. 2016, 2018; Benneworth and Jongbloed 2013; Larédo 2007; Sandman 2008).

From a historical perspective, several stages can be discerned in the development of university-society relations (Charles 2011; Bender 1988). In an early "monastic" stage, universities were self-contained and relatively secluded, often sited within the urban core. Their morphology evolved from monastic traditions: gated cloisters where teaching took place within the walls, with very little interaction with the outside world (beyond being the object of study). Such campuses functioned as a closed/walled city within the city, with internal courts and gardens, aimed to foster reflection and internal debate rather than interaction with the city or society at large.

From the late nineteenth century (following the shift to the Humboltdian research university and American civic university), universities started to develop campuses on the fringes of the city, or at more central locations to ensure accessibility by students. In line with then-current architectural views on functional separation, campuses were typically conceived as mono-functional areas for research and higher education only. Increasing mobility throughout the 20th century gradually drove the separated university campuses to more remote locations, with large parking lots for commuting staff, and connected to the city via public transport.

In the last two decades of the 20th century, universities became perceived-or framed themselves-as engines of local and regional knowledge-based development, in their capacity as developers of knowledge technology and innovation, as attractors/providers of human capital, and as cradles of new firms. In response to de-industrialisation in the 1970s and 1980s, cities and regional governments started to focus on knowledge-based development as an economic strategy, and turned to universities as agents of economic development (Ischinger and Puukka 2010; Chatterton and Goddard 2000; Charles 2006).

Universities increasingly capitalised on the economic value of their knowledge, research, and technology, and increased their income from patenting, licensing, contract research, professional training programmes, and spin-off companies. Universities set up dedicated organisational units such as technology transfer offices, incubators, and training agencies, as professionalised intermediaries between business and academia. Technical or medical universities/faculties, often in collaboration with 
local governments and developers, started to develop science parks where universities and technology businesses are co-located with the vision to share equipment, develop viable new technology and innovations, and create high-tech firms and jobs in a synergetic environment. In this stage, most of the university-society interaction is confined to technical and medical (including biotech) universities or departments, and predominantly has an economic orientation.

In the last decades, the economic aspects of collaboration are complemented with broader forms of engagement, with the proliferation of related concepts and ideas such as Mode 2 science, triple helix formations, engaged research, service learning, transdisciplinarity, living laboratories, applied innovation, and the co-production of knowledge (Gibbons 1994; Nowotny et al. 2001; Evans and Karvonen 2014). Also, new conceptualizations of the university are developed, such as the entrepreneurial university (Clark 2004), the civic university (Goddard and Vallance 2013), or the engaged university (Watson et al. 2011).

This stage sees engagement expand in at least three respects: (1) a broadening from a Science, Technology, Engineering and Mathematics (STEM) orientation towards other disciplines and other sectors; (2) the recognition and positioning of the university as vital player in solving societal challenges such as ageing, climate change, and energy transition, triggering more integrated and interdisciplinary approaches and links with a broader set of societal actors; and (3) a stronger embeddedness or integration of educational programmes (rather than only research) with society, reflected in the proliferation of service learning, problem based learning, and similar types of education strategies (Doberneck et al. 2010). It is important to note that levels and degrees of engagement vary strongly between institutions of higher education (see, for instance, McMillan and Overall (2016) for a critical analysis of top business schools and Masters of Business Administration (MBAs) in this respect).

The role of geographical proximity is a key topic of debate in the literature on university engagement. Many studies emphasize the key role of geographical proximity in facilitating knowledge exchange (Bathelt et al. 2004; Cooke 2001; Maskell 2001; Morgan 2004; Storper and Scott 1995; Storper and Venables 2004). Proximity facilitates face-to-face contact, enabling the formation of 'swift trust' (Brown and Duguid 2000; Gertler 2001; Morgan 2004). Moreover, physical proximity helps to foster other forms of proximity (cognitive, social, organizational, and institutional) (Boschma 2005). Laursen et al. (2011) empirically find that firms' decisions to collaborate with universities are influenced by geographical proximity to universities and the quality of the university. Proximity to a lower-tier university (as in our case study) would reduce firms' propensity to collaborate locally, but this effect applies to firms that are highly research \& development (R\&D) intensive (unlike the firms in our case study).

Sánchez-Barrioluengo and Benneworth (2019) note that most studies on engaged or entrepreneurial universities implicitly assume that the engagement is one of the core purposes of the university, and treat university structures as rather simplistic and functional, as if they are homogeneous organisations run by a management that is in full control over strategy. Building on Burton Clark's work (Clark 2004), they recognize the role of the complex internal workings of the university, and propose a more refined, layered view of how the university's structural elements influence its entrepreneurial behaviour or engagement, identifying four key elements: (1) the role of the central steering core: how senior managers articulate a shared vision and strategy, lead the institution, and provide legitimacy to engagement; (2) the administrative apparatus: the degree to which the university's administration supports the entrepreneurial or engagement strategy through rules, procedures, incentives, and support structures; (3) the efforts and commitment of the academic heartland: how academic staff engage with society, recognizing new opportunities and using the support; and (4) the degree of internal coupling: how the more peripheral external, engagement activities, and structures are coupled to core activities of the university (research and education programmes), so that synergies emerge. On the basis of these elements, various types of universities can be discerned. For the United Kingdom, they distinguish between three groups: elite universities in the Russell group; other research universities; and post-1992 
universities that developed from university college status, and were characterized by mostly training, and less active in basis research.

\section{Engagement and Intermediation}

It has become common for universities to have intermediate bodies to foster, structure, professionalize, and institutionalize their interaction with society. The most prevalent (and best documented) types are technology transfer offices, incubators, science parks, and co-creation concepts (see, among many others, Guston 1999; Derrick 2015; Boh et al. 2016; Phan et al. 2005; Löfsten and Lindelöf 2002; Hobbs et al. 2017; Markman et al. 2005). Typically, these bodies have an economic orientation, and aim to valorize academic knowledge, create spin-off companies, or systematically foster links with R\&D intensive private firms. More recently, we see the creation of new types of intermediaries with a wider mission of connecting research and education with society. Although there is existing literature on universities as knowledge intermediaries (e.g., Benneworth and Sanderson 2009), such newer forms and types have been much less explored and studied, especially those developed by higher education institutions (HEIs) such as universities of applied sciences or university colleges.

For our purposes, the broader literature on innovation intermediaries provides valuable insights and conceptualisations (Howells 2006; Agogué et al. 2017). In fact, university-society interaction processes resonate with many other contemporary architectures of learning where intermediation became valued as the "art" of connecting cognitive and socially distant actors (Boltanski and Chiapello 1999). Howells (2006) defines an intermediary as "an organization or body that acts as agent or broker in any aspect of the innovation process between two or more parties" (p. 720). Regeer et al. (2016) describe intermediaries as "boundary people" that "bridge or create alignments between different worlds" (p. 16). Recent studies show that their function is not only to be middlemen, connecting users and suppliers of new knowledge, technologies, or innovations; they are more deeply interwoven in innovation processes themselves, and play an active role in co-shaping innovations along various stages and cycles. They can reduce uncertainty and mediate complex interactions between multiple actors resulting in innovation (e.g., Van de Ven et al. 1999).

Several roles and activities can be discerned: facilitating learning and collaboration in networks; managing and allocating financial and human resources; the articulation of client needs and requirements; prototyping and piloting; arbitration and brokering; accreditation and setting standards; investment appraisal and business planning, and training, education; and communication (Bessant and Rush 1995; Howells 2006; Klerkx and Leeuwis 2009). Stewart and Hyysalo (2008) discern three key activities of university-society (U-S) intermediaries: facilitating, configuring, and brokering (Table 1).

Table 1. Roles of innovation intermediaries.

\begin{tabular}{ll}
\hline Role & Description \\
\hline \multirow{3}{*}{ Facilitation } & Provision of spaces and equipment \\
& Access to networks and communities \\
& Access to funding \\
& Access to external knowledge \\
& Promotion and marketing \\
& Providing room for experimentation \\
\hline \multirow{2}{*}{ Configuring } & Aligning perceptions and expectations on both sides \\
& (Re)interpreting/valuating solutions and innovations \\
\hline \multirow{2}{*}{ Brokering } & Communication and negotiation between university and external stakeholders \\
& Providing access to new networks or resources \\
\hline
\end{tabular}

Facilitation is the process of creating opportunities for others and new environments to ignite innovation. Facilitation helps to make co-creation easier for involved parties by developing and 
providing access to equipment or rooms, but also to networks and communities, to funding sources, or to broad types of knowledge-including, for example, expertise and knowledge about the other party's mindsets, interests, and behaviours. Facilitation can also include promotional efforts to increase the visibility of innovations within and outside organizations; or the creation of flexible (regulatory) arrangements that reduce uncertainty and facilitate experimentation (Regeer et al. 2016; Lember et al. 2014).

Configuring activities are efforts by intermediaries to adapt, arrange, or adjust innovations and products with a view to specific applications or uses (Stewart and Hyysalo 2008). It involves active listening, and moderating discussions that shape the perceptions of both sides about a certain project, solution, or technology, contributing to its valuation and appropriation. It also involves the configuring of intermediaries and priority setting processes and judgements, identifying the most relevant uses of a solution for a specific challenge. Thus, configuration has a strong symbolic and discursive component of (re-)interpreting and framing knowledge and innovations to the views and expectations of relevant audiences and stakeholders, while ascribing value-and values— to them (Huguenin and Jeannerat 2017; Carvalho and Winden 2018).

Finally, brokering can be pivotal to bridge the different social and institutional realms of university and society. Stewart and Hyysalo (2008) see brokering as a process of communication and negotiation about contracts, functionalities, and all sorts of implementation challenges that collaborating innovating parties face. Brokering plays a role in building or maintaining trust (e.g., Boltanski and Chiapello 1999). It can also help to secure resources and to maintain interest in the innovation, helping to raise new constituencies (also Edler and Yeow 2016). Brokering may be fundamental to access resources across, for example, administrative levels and navigate complex hierarchies and power structures of the university and organizations with which it wants to engage.

Intermediaries fulfil these three roles throughout different stages of university-society interaction, removing possible hurdles that could prevent rich and fluid conversations from unfolding. Lester and Piore (2004) adopt the metaphor of the "cocktail party" hosts, who have the task to invite the guests, initiate the conversation, keep it going, and refresh it with new ideas and proposals.

Thus, innovation intermediaries are much more than simple middlemen. Agogué et al. (2017) depicts the intermediary as an architect in the form of a co-creator and enabler of collective knowledge creation. In their three roles, they strongly influence the evolving shape of conversations, interactions, and innovative outcomes. Their choices and actions are not neutral, but will reflect their values, interests, and preferences.

\section{Case Study: The Knowledge Mile}

In this section, we describe the KM as an innovative case of intermediation in the U-S interaction. The analysis is based on a review of reports and websites, complemented by seven in-depth semi structured interviews with the founder of the Knowledge Mile, street managers (2), a community manager, a board member of the KM organisation, a local company, and a local government representative. The interviews were carried out during January-May 2019, lasted for about one hour each, and were transcribed afterwards. They focused on topics such as perceptions of the Knowledge Mile; incentives and barriers to participate in activities; their view on community formation, learning processes, innovation processes, and outcomes; and the role of public spaces and proximity.

Data were structured along three key aspects of intermediation: facilitation, configuring, and brokering, in the two main stages of the organization's lifespan. Although the authors of this paper are all employed at AUAS, they have had no active role in the Knowledge Mile organisation, so they they can be regarded as neutral observers.

The Knowledge Mile (KM) concept was launched in 2015 by the Amsterdam University of Applied Sciences (AUAS, or HvA in Dutch) to transform and reframe, rebrand, and rename the $2 \mathrm{~km}$ long urban access route (the Wibautstraat continued into the Weesperstraat, see Map (Figure 1) that runs from south to east into the center of the city, in which the main AUAS campus is situated. The vision behind this 
was twofold: first, to turn the area into a living lab, enabling AUAS students, teachers, and researchers to engage with actors in the area for research or education projects; and second, to collectively develop the area into a more attractive street. The university management installed a dedicated Knowledge Mile (KM) team, tasked to work as intermediary between the (many) actors in the street on the one hand, and the university departments, academics, and students on the other, to forge new links and relationships, as well as to foster the development of projects. Later, after a pioneering stage, the KM team took the initiative to institutionalise the Knowledge Mile into a BIZ (business investment zone), a concept similar the BID (business improvement district) in the Anglo-Saxon world (Ward 2006). Since then, the Knowledge Mile has evolved from a local living lab into a hybrid between a BIZ, a city marketing concept, a living lab (a lot of smart-city like innovation projects are done by students and researchers teams in the street), and an organised business community.

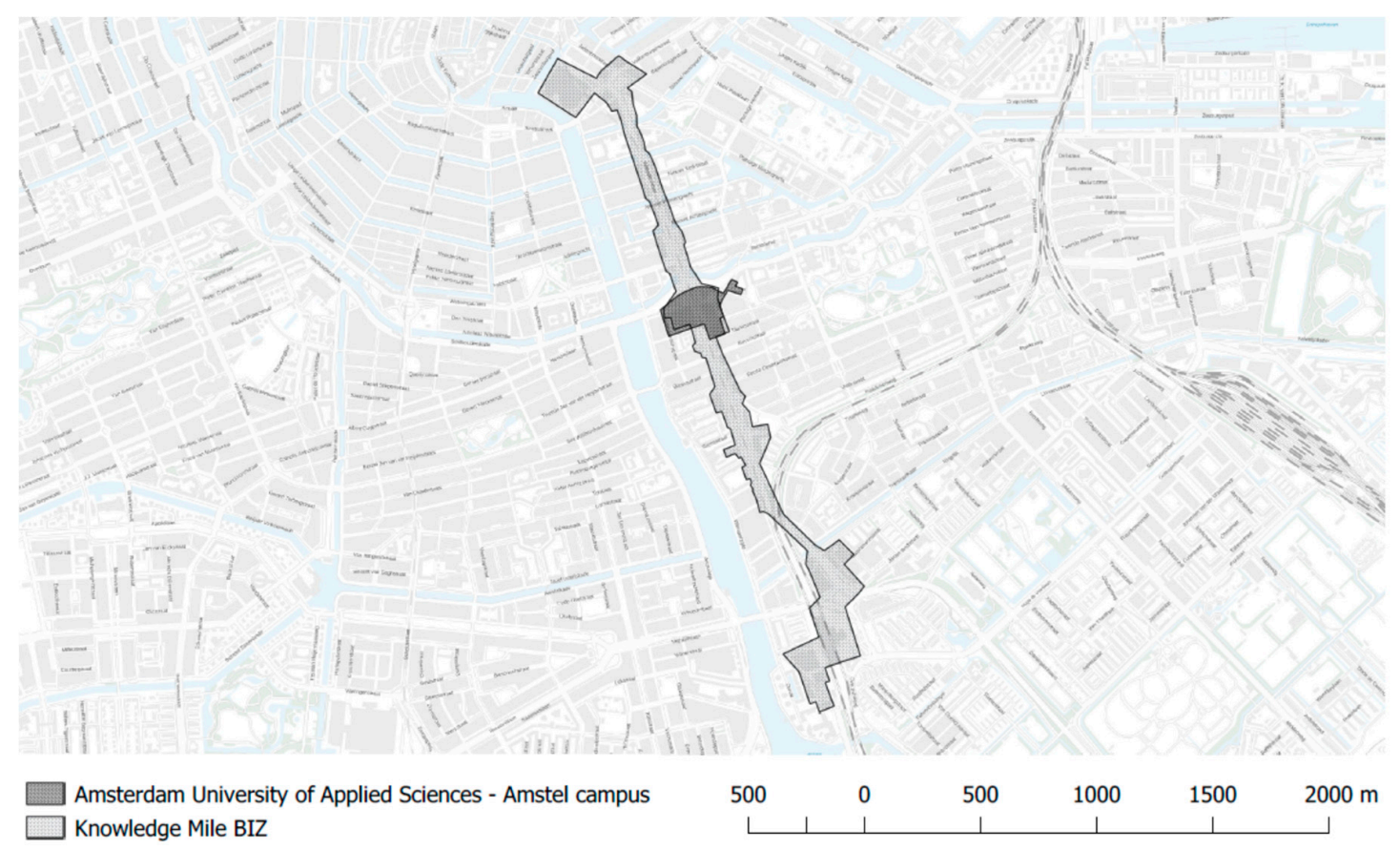

Figure 1. Map: The Knowledge Mile. BIZ, business investment zone.

\subsection{Background: Amsterdam University of Applied Sciences (AUAS)}

AUAS is the largest university in Amsterdam, with 46,000 students studying at seven faculties. It is a university of applied sciences (UAS) ${ }^{1}$, which gradually evolved from a university college (with Bachelor's education only, and no research) into a more comprehensive university. AUAS currently has about 50 professors, specialising in applied research fields, and still mainly offers Bachelor's programmes, although the number of Master's programmes is increasing. The university has several campuses, but the main one is the Amstelcampus, a mix of new and refurbished buildings, situated east of the city centre, along the Wibautstraat, a key urban artery. Since 2011, the Amstelcampus has been developing, and it is now home to four faculties and 27,000 students and staff. The development of this large campus sped up the process of gentrification in the eastern part of Amsterdam. Offices in the street are being filled with creative companies and co-working spaces, trendy coffee bars have opened, and real estate prices are rising fast in this area that used to be considered as grey and unattractive.

1 The dual Dutch higher education system has two types of universities: research universities and universities of applied sciences (UAS), with the latter type spending relatively little on research compared with research universities. 
AUAS has engagement as a core part of its mission; the organisation supports engaging academics in several ways, and the core research and education activities of the university are, to a substantial degree, oriented to the external environment. Table 2 describes how the AUAS could be positioned along the four structural elements identified by Sánchez-Barrioluengo and Benneworth (2019) that influence society engagement.

Table 2. Structural elements favouring engagement activity (as identified by Sánchez-Barrioluengo and Benneworth 2019). AUAS, Amsterdam University of Applied Sciences.

\begin{tabular}{ll}
\hline \multicolumn{1}{c}{ Structural Element } & \multicolumn{1}{c}{ AUAS } \\
\hline $\begin{array}{l}\text { Vision, strategy, leadership, legitimacy } \\
\text { for engagement }\end{array}$ & Engagement is central part of mission, vision, and leadership \\
\hline $\begin{array}{l}\text { Rules, procedures, incentives, } \\
\text { and support structures }\end{array}$ & $\begin{array}{l}\text { Academic staff are actively encouraged to engage with societal } \\
\text { actors; engagement is a key performance indicator for research } \\
\text { activity; intermediaries are in place }\end{array}$ \\
\hline $\begin{array}{l}\text { Efforts and commitment of the } \\
\text { academic heartland }\end{array}$ & $\begin{array}{l}\text { Large numbers of teachers and professors actively engage with } \\
\text { society, it is part of academic culture }\end{array}$ \\
\hline $\begin{array}{l}\text { Coupling of external, engagement } \\
\text { activities to core activities of the university } \\
\text { (research and education programmes) }\end{array}$ & $\begin{array}{l}\text { Many educational programmes have open modules for } \\
\text { problem/challenge based learning and action learning; } \\
\text { societal actors and judged accordingly; Action research } \\
\text { is widespread }\end{array}$ \\
\hline
\end{tabular}

Like most UAS in the county, AUAS has a long tradition of close collaboration with actors in the professional field for which it educates its students. Engagement with the local society is-and always has been - a central part of its mission: " . . by connecting education and applied research, the AUAS enables innovation in the professional sector and community in, and around, the cosmopolitan city of Amsterdam" ${ }^{\prime 2}$. Moreover, in its educational philosophy, the university puts emphasis on practice-based learning, seeking to offer "an interactive learning environment, where our students learn, as much as possible, through realistic professional practice situations and via an interdisciplinary approach to solving complex issues". Also, the university explicitly sees a role for itself in addressing urban challenges: "As a knowledge institution, the AUAS inspires students to create tomorrow by forging creative solutions and sustainable innovations to urban challenges".

Academic staff in all faculties are actively encouraged to adopt teaching methods in which learning is organised around real-world problems or challenges. The university has a large number of minor courses and other modules in which engagement is built-in. In general, academic staff have substantial autonomy as to the projects they bring in and the methods they apply. On the research side, over the last decade, AUAS has developed its research profile around action research methods, with a strong orientation to develop practical solutions with and for stakeholders. Professors are expected to co-develop new knowledge and innovations in their field, not for the sake of new knowledge, but to contribute to society and to renew academic curricula. Their research activities are evaluated on knowledge production (measured in academic publications), but also patents, artefacts, contribution to society, and contribution to curriculum renewal.

The university runs several intermediary organisations that help to mediate relations with society. Through the BOOT ${ }^{3}$ initiative, AUAS has created small "shops", located in four deprived neighbourhoods in Amsterdam, where students from various faculties engage with local residents and companies (and gain credits). Business students help small firms to develop business plans or with debt management, law students offer legal advice to residents, teaching students help in homework

2 http://www.amsterdamuas.com/about-auas/profile/mission-and-vision/mission-and-vision.html.

3 BOOT is the "Neighborhood shop for Education, Research and Talent development" (better known as: "Buurtwinkel voor Onderwijs, Onderzoek en Talentontwikkeling" in Dutch) http://www.hva.nl/boot. 
support projects, and so on. In each BOOT location, the university provides a coordination team that manages the programme, recruits the students, and maintains the contacts with the academic staff, working closely with social organisations in the local community.

Since 2014, the university has provided additional funding for interdisciplinary research programmes that address urban challenges. Centres of expertise were created in the fields of urban management (coordination and governance of complex urban problems), urban vitality (health, ageing), urban technology (smart city solutions), and urban education (lifelong learning, managing diversity, parental engagement in education), and each centre has developed a range of research projects with stakeholders in the city. A map was developed to show all the activities of AUAS in the city: https://hvaindestad.nl/kaart.

\subsection{The Knowledge Mile}

It was from this engagement culture of the AUAS that the idea to start the Knowledge Mile was born. The initiative to develop the KM was taken in 2015, by the dean of the faculty of Digital Media \& Creative industry, one of the faculties that is located at the central Amstel Campus. The faculty had received extra funding from a national programme to set up a "centre of expertise". Following discussions on how to connect the universities' activities to urban challenges-in line with the AUAS strategy - the idea was born to take a hyper-local approach and focus on developing deeper and more long-term relations with actors in the direct vicinity of the campus. The inventor of the KM-who later became the project leader-stressed how he needed a compelling story, framing the Knowledge Mile as an initiative in which university and local stakeholders would join up to transform this "ugliest street of Amsterdam", as it is known by many, into something innovative and attractive. The diversity of the street was seen as an asset, with its wide variety of companies and organisations, ranging from retail, hotels, restaurants, and car repair shops, to advanced service providers and public institutions. This diversity was also seen to fit the academic diversity of the AUAS faculties. Using the word "university" in the name of the initiative was deliberately avoided; the team feared that would have given the concept too much of an academic flavour (which might deter smaller companies to participate), and would have positioned the AUAS too strongly as a central and dominant factor.

The KM was set up as a small project team, with a project manager, a community manager (responsible for developing relations with companies in the street and within the AUAS), and a small support staff. In the first months, the team put much effort to "get to know the neighbours", individually visiting companies, meeting community leaders and local government staff, but also to undertake internal networking with academic staff responsible for educational or research programmes. This resulted in a series of smaller innovation projects, mainly by students working on assignments for companies. KM intermediated to link implicit or explicit research and innovation questions of local organisations to individual students or to students' teams, from minor courses or other modules in which students work on real world assignments. The KM team facilitated the initial contact, but in many cases, also helped to (re)formulate the assignment, translate it into a manageable education assignment, and manage expectations on both sides.

As a means to reach more people/organisations and develop larger projects, the KM started to develop meetups in the street: short open meetings (typically early morning), on average once every two months, hosted by volunteering companies in the street, where local actors and university staff could get to know the host, share results of innovation projects, and explore ideas for new collaborations. The meetups helped to establish connections, but also created a stronger bonding among businesses and other organisations. The KM organisation, as spider in the web, developed a database with meetup participants and projects.

Many innovative projects are currently being developed. A rooftop garden is being remodelled and expanded after the Amsterdam Fashion Institute successfully used it to grow environmentally friendly dyes for the textiles industry. Another roof will be used to test a new system for blue-green roofs, that can store water and grow plants on it. Further down the street, a reservoir was installed 
on the top of an office block, to collect rainwater to brew beer. It grew into a project called "heavenly water" (later, Rainbeer). Table 3 provides a small sample of the projects. A total of 800 students from a wide variety of disciplines have worked on one of the projects at the KM so far.

Table 3. Some project examples.

\begin{tabular}{ll}
\hline Project Title & Project Description \\
\hline Measuring greening & $\begin{array}{l}\text { Students of applied mathematics develop tools for how to measure the } \\
\text { process of greening the Knowledge Mile (KM) }\end{array}$ \\
\hline Smart bees & Students installed smart beehives on rooftops \\
\hline Safe street & $\begin{array}{l}\text { Student teams develop concepts to make the street safer street using } \\
\text { design thinking tools }\end{array}$ \\
\hline Data visualisation & Students made data visualisations on several aspect of KM \\
\hline Dust sensors on rooftop & Students installed sensors on rooftop to analyse dust and small particles \\
\hline KM PET free & Larger programme to make the street free of PET plastics \\
\hline
\end{tabular}

As the KM became better known—thanks to substantial local and national media coverage and word-of-mouth-it started to attract the attention of companies outside KM that saw opportunities to use the network to test new concepts. As an example, Dopper, a manufacturer of water bottles, launched the challenge to make the street free of clear plastic, also known as polyethylene terephthalate (PET), bottles. Intermediated by KM, it invited teams of students and researchers to develop concepts and solutions for this purpose.

\subsection{Stage 2: KM Becomes a Business Investment Zone (BIZ)}

In mid-2016, the community manager of KM attended a presentation about business investment zones (BIZ). Under Dutch law, a BIZ is a delineated urban area (a street, square, or business park) in which entrepreneurs and/or real estate owners invest together in the quality of their business environment. All businesses in the BIZ contribute financially. To create a BIZ, companies need to present a plan, outlining the activities and required budgets. If the city agrees with the plan, and if there is enough support among businesses and/or owners, the city council imposes (and collects) a levy for all companies or owners in the area (BIZ-fee), in order to prevent freeriding. The revenue is then made available to the BIZ organisation as a subsidy.

The idea was born to turn the KM into a BIZ. This would give KM much more financial and organisational clout, and open new opportunities for larger projects. The (still small) KM team took the initiative to launch the bid: writing a plan and, above all, developing support among the street's businesses and convincing them to sign up. For the latter, the KM team relied on its big network in the street, and the good reputation it had earned as a trustworthy intermediary partner. After an intense period of lobbying and reaching out to all businesses in the street, the BIZ plan for the Knowledge Mile was written, and received enough support among the businesses in the street. It was accepted by the city council, and came into action from January 2017. A dedicated BIZ organisation was set up, managed by a board of five people (three company representatives, one manager of a collective, and a member of the board of AUAS). The daily work is done by two street managers and a "learning community manager" from the university. KM has an annual budget of around EUR 225,000, from which EUR 125,000 is generated by the businesses and EUR 100,000 is delivered in-kind by the Amsterdam University of Applied Sciences.

The new phase provided for more financial and organisational clout, but also changed the role and identity of the KM. In the early stage, its core mission had been to develop innovations with "coalitions of the willing", consisting of companies and academics. In the new phase, it has to play a balancing act of serving the interests of all the companies in the street, because now they all contribute financially and expect something in return. Two freelance "street community managers" were hired: one to connect with retailers and firms with a public function, and the other to deal with larger firms 
or service firms without street presence. The street managers are tasked to develop activities that add value for these target groups, focusing on improving public space, and many new projects have no explicit link with AUAS research or education. For instance, a "knowledge trail" was organised, an obstacle run through office buildings on the Knowledge Mile for employees and business owners, as well as an exchange network for human resources (HR) professionals of firms, was set up.

KM has a strong incentive to deliver value added to the firms in the street: according to the Dutch regulations, after four years, the BIZ has to be renewed based on a vote among all firms in the street, in which the turnout must exceed 50\%, and two-thirds of the voting companies must vote in favour ${ }^{4}$. The original role of the AUAS as innovation broker is still in place. The development of innovation projects is now one of the action lines in the BIZ strategy. In the KM board, the AUAS KM project manager has been replaced by a member of the board of the university, giving KM a more prominent position in the university hierarchy.

The new structure creates tensions at times, for example, as to who is the main contact person for companies. As one of the street managers put it: "I must make sure that companies are not bothered by too many students". The most ambitious initiative of KM is the creation of the Knowledge Mile Park (KMP), an ambitious plan for greening the street. It includes the creation of rooftop gardens, greening public spaces, and the coordination of the creation of façade gardens by inhabitants and businesses. The core idea behind KMP is give local communities (which are now better connected organised thanks to the Knowledge Mile) a strong role in the design and maintenance of green spaces. Knowledge Mile Park is led by a project manager of the city, who coordinates the actions of inhabitants, community groups, companies, and various municipal departments and local boroughs. Knowledge Mile Park can be seen as an experiment of place making, in which the design and maintenance of the public space is co-created by local communities and various government departments. The role of AUAS here is rather limited.

Table 4 summarizes the activities of the KM in its two stages, structured along the three aspects of intermediation: facilitation, configuring, and brokering (as discussed in the previous section). Since its inception, facilitation has been the primary role of the KM: providing access to networks and communities, access to external knowledge, funding, promotion and marketing, and providing room for experimentation. In the second stage, a shift of emphasis can be observed from facilitating innovations with AUAS staff and students towards creating larger projects, often with local government bodies, to improve public spaces. When it comes to configuring activities, the KM team helps to align expectations of companies and students/academics in collaborative projects. This is important especially for firms with no prior experience of working with AUAS and no knowledge of what they can expect in terms of quality and process.

Also, the KM as an intermediary helps to (re)interpret and valuate prospective solutions and innovations, and thus pays an active role in shaping the outcome. For example, in the challenge to make the street plastic-free, KM moderated the discussion between the bottle company, retailers, city administration, and student/researchers groups about alternative and complementary measures, when it turned out that banning plastic was impossible. This resulted in the provision of public water tap points in the street, to encourage the public to refill their bottles rather than buying new plastic ones.

In the second stage of $\mathrm{KM}$, its configuring role shifted towards moderating the collaborative valuation of public space improvements (with or without AUAS engagement); the prime example is the Knowledge Mile Park project. When it comes to brokering, KM team's main role was initially to connect AUAS staff and students to local companies (the negotiation of project details was then left to the project partners). Now, however, the emphasis has shifted to communication and negotiation between the BIZ management and its members, and with local government agencies. AUAS plays a secondary role.

4 https://www.amsterdam.nl/ondernemen/biz/toolkit-biz/. 
Table 4. Summary of results. BIZ, business investment zone.

\begin{tabular}{|c|c|c|c|}
\hline General & Aspects & KM Phase 1 & KM Phase 2 \\
\hline \multirow[b]{3}{*}{$\mathrm{KM}$} & $\begin{array}{l}\text { Organisation and } \\
\text { management }\end{array}$ & $\begin{array}{l}\mathrm{KM} \text { is managed and led by a small } \\
\text { internal AUAS team, and operates } \\
\text { rather informally }\end{array}$ & $\begin{array}{l}\mathrm{KM} \text { is formally organised as business } \\
\text { improvement district with AUAS on the } \\
\text { board along with other local organisations }\end{array}$ \\
\hline & Funding & $\begin{array}{l}\text { Funding for two staff members } \\
\text { by AUAS }\end{array}$ & $\begin{array}{l}\text { Substantial funding from BID } \\
\text { contributions of all business in the street }\end{array}$ \\
\hline & Main activities & $\begin{array}{l}\text { (1) Initiating and fostering innovation } \\
\text { projects between } \\
\text { academics/students/research groups } \\
\text { and actors in the street } \\
\text { (2) Demand articulation } \\
\text { (3) Mediating between companies in the } \\
\text { street and AUAS } \\
\text { teachers/researchers/students }\end{array}$ & $\begin{array}{l}\text { Three key themes to work on: (1) Talent } \\
\text { and network (creating communities and } \\
\text { learning exchanges); (2) Safety and public } \\
\text { space; ( } 3 \text { ) Green and sustainable }\end{array}$ \\
\hline & & $\mathrm{KM}$ as innovation intermediary & \\
\hline \multirow{6}{*}{ Facilitation } & $\begin{array}{l}\text { Provision of spaces and } \\
\text { equipment }\end{array}$ & $\begin{array}{l}\text { KM does not have its own spaces or } \\
\text { equipment, apart from a small office; } \\
\text { projects are embedded in existing } \\
\text { spatial structures or at partners } \\
\text { premises }\end{array}$ & Idem \\
\hline & $\begin{array}{l}\text { Access to networks and } \\
\text { communities }\end{array}$ & $\begin{array}{l}\text { Local meetups and other events were } \\
\text { designed to connect AUAS staff with } \\
\text { local companies and communities in the } \\
\text { street; KM team functions as access } \\
\text { point for local companies that want to } \\
\text { collaborate with AUAS, or vice versa }\end{array}$ & $\begin{array}{l}\text { More focus on (1) topic-specific exchange } \\
\text { between companies in the street and } \\
\text { (2) connections to local government }\end{array}$ \\
\hline & Access to funding & $\begin{array}{l}\text { Most innovation projects did not require } \\
\text { funding as they were incorporated in } \\
\text { current educational programmes }\end{array}$ & $\begin{array}{l}\text { KM facilitates/accelerates access to local } \\
\text { government funds, mainly for } \\
\text { improvement and greening of public } \\
\text { spaces }\end{array}$ \\
\hline & $\begin{array}{l}\text { Access to external } \\
\text { knowledge }\end{array}$ & $\begin{array}{l}\text { Local meetups attracted also players } \\
\text { from outside the KM, fostering new } \\
\text { innovative partnerships between AUAS } \\
\text { and the city }\end{array}$ & $\begin{array}{l}\mathrm{KM} \text { is a member of Campus Amsterdam, } \\
\text { a knowledge exchange network between } \\
\text { campus areas in the larger Amsterdam } \\
\text { region }\end{array}$ \\
\hline & Promotion and marketing & $\begin{array}{l}\text { Focus on marketing/rebranding the } \\
\text { street as local innovation lab }\end{array}$ & $\begin{array}{l}\text { Focus on place-making in general, } \\
\text { promoting the street as attractive business } \\
\text { environment }\end{array}$ \\
\hline & $\begin{array}{l}\text { Providing room for } \\
\text { experimentation }\end{array}$ & $\begin{array}{l}\text { KM actively invited AUAS and local } \\
\text { partners to set up all sorts of } \\
\text { experiments in the street, depending on } \\
\text { needs and interests }\end{array}$ & $\begin{array}{l}\text { Experimentation with new roles of local } \\
\text { government as partner in the BIZ }\end{array}$ \\
\hline \multirow[t]{2}{*}{ Configuring } & $\begin{array}{l}\text { Aligning perceptions and } \\
\text { expectations on both sides }\end{array}$ & $\begin{array}{l}\text { KM team moderated discussions } \\
\text { between company and } \\
\text { researchers/students in initiation stage } \\
\text { of projects, to align expectation and } \\
\text { perceptions of innovation projects }\end{array}$ & $\begin{array}{l}\text { Now also includes aligning the } \\
\text { perceptions and actions of companies, } \\
\text { citizens, local government, and BIZ } \\
\text { regarding the development of public } \\
\text { space and greening of the street. }\end{array}$ \\
\hline & $\begin{array}{l}\text { (Re)interpreting/valuating } \\
\text { solutions and innovations }\end{array}$ & $\begin{array}{l}\text { KM mainly played a role in the initial } \\
\text { stage of projects }\end{array}$ & $\begin{array}{l}\text { BIZ manages an ongoing process of } \\
\text { interpretation of solutions with local } \\
\text { citizens and companies }\end{array}$ \\
\hline \multirow{2}{*}{ Brokering } & $\begin{array}{l}\text { Communication and } \\
\text { negotiation between } \\
\text { university and external } \\
\text { stakeholders }\end{array}$ & $\begin{array}{l}\text { KM team's main role was to connect } \\
\text { AUAS staff and students to local } \\
\text { companies; negotiation of project } \\
\text { details was left to the project partners }\end{array}$ & $\begin{array}{l}\text { More focus on communication and } \\
\text { negotiation between the BIZ management } \\
\text { and its members, and with local } \\
\text { government agencies; AUAS plays a } \\
\text { secondary role as knowledge partner }\end{array}$ \\
\hline & $\begin{array}{l}\text { Providing access to new } \\
\text { networks or resources }\end{array}$ & $\begin{array}{l}\text { KM's activities led to the establishment } \\
\text { of new personal networks between } \\
\text { AUAS local companies; also, KM } \\
\text { attracted the attention of external } \\
\text { companies interested in using the } \\
\text { street-based innovation community as a } \\
\text { test bed for their innovations }\end{array}$ & $\begin{array}{l}\text { BIZ formation opens new doors in local } \\
\text { government agencies, and expanded the } \\
\text { financial clout of KM through } \\
\text { membership fees; it also led to active } \\
\text { participation of larger players such } \\
\text { as Philips }\end{array}$ \\
\hline
\end{tabular}

\section{Conclusions}

Universities are becoming more engaged with society, and this interaction is mediated in a variety of ways. There is a lot of literature available on the intermediation of economic knowledge and technology transfer, on knowledge transfer offices, incubators, and science parks, or how universities 
integrate societal engagement into their teaching and training programmes. Much less explored is the question of how universities deploy intermediary structures to realize their ambition to address (local) societal challenges, or that support the development of real-life and case-oriented types of research and education.

\subsection{KM as a Case Study Example}

This paper intends to make a contribution in this field, and describes how AUAS is engaging with its immediate urban surroundings in novel and more comprehensive ways through the Knowledge Mile. The KM is an intermediary organisation and a branding concept at the same time, created by AUAS to systematically connect teaching and research activities to its immediate surroundings and reframe/rebrand the rather unattractive urban street in which the university is located as a living lab. KM is a prime case where engagement with the urban society is not only a token in the universities' vision and strategy, but became formally institutionalised into the university, structurally funded and appreciated.

As intermediary body, the Knowledge Mile enables teachers/professors to engage with local firms, helps them to find partners and articulate research questions and challenges (by organising meetups and other community-building efforts), and supports the formation of innovation projects of all kinds. A key contribution of KM is to provide a framework for researchers and teachers to co-innovate with local stakeholders and communities, incorporating individual projects into a broader narrative of local place making and addressing societal challenges next door. The media coverage and strong communication and promotional efforts by the KM team lend credibility to the Knowledge Mile concept and seduces AUAS staff to participate. Also, KM offers support in designing research questions and creating multidisciplinary teams from various academic tribes, forging new linkages and knowledge exchange. KM helps to mobilise engagement, and channels it into the local area. KM thrives on the motivation and willingness of individual researchers and teachers who see value in connecting their education or research work to local innovation projects.

KM has developed-and is recognized as-a "provider" of real-world innovation projects, which are greatly in demand; at AUAS, there are many educational modules in which learning is organized around real-world projects, and KM facilitates professors to develop these. This is typical for universities of applied sciences in the Netherlands (and abroad), but much less so for many research universities. The monthly community meetups have proven to be an effective method to get into contact with local stakeholders and communities that otherwise would have been much more difficult to reach. The KM team plays the role of cocktail host, providing "conversation spaces" to discuss challenges, problems, and innovation needs, and to develop ideas on how the university could help address them.

Although conversations and interactions between academic staff and external actors can be (and often are) direct, they are intermediated through a dedicated organisation or policy programme that contributes to shape the interaction environment. The mix of plenary activities and informal gatherings afterwards helped to articulate and debate very local challenges, and enabled to forge new coalitions of local stakeholders with similar challenges and research questions. The consistent focus of the KM team on re-imaging the quality of and innovative character of the urban street (rather than pursuing the narrower academic interests of the university) gave the KM concept a wide appeal among stakeholders in and outside the area, and lent the university credibility as intermediating partner.

It is debatable to what extent KM is replicable in other contexts. The academic, spatial, and policy setting of AUAS is rather unique; its long tradition of action learning and engagement, a recent but strongly growing emphasis on applied research, and its relatively new central urban campus. All were important contextual factors that facilitated the development of the KM and helped reach a higher level of local engagement. KM is a case where engagement is achieved by moving beyond one-off or ad-hoc projects or ad-hoc linkages with society. The scope, depth, and endurance of engagement is enhanced with AUAS becoming an active and structural member of the local community. Importantly, the university does not position itself as a high-level problem solver or superior supplier of knowledge 
and expertise from which the local society can benefit; rather, it has an explicit agenda, in line with its core academic vocation, to create a local learning environment and a real-world living lab, and it needs the local community to achieve that.

\subsection{Broader Impact of the KM Case}

The KM case enriches the literature on university-society engagement in several respects. It defies the often-stated dichotomy in the literature between the university, portrayed as having "knowledge", and the local communities, which have not, speaking of engaged universities as "placing their knowledge at the benefit of communities" as in Benneworth et al. (2018). In the KM, a more radical idea of co-creation has been adopted, recognizing that value emanates from co-design of local communities or SMEs - bringing in their practical and experiential knowledge-with more conceptual knowledge and problem-solving skills of researchers and academics.

In line with the literature, our case confirms the significance of geographical proximity as enabler of knowledge exchange in the university-society interaction. Where most of the academic literature focuses on research intensive universities and their relation with industry, our case highlights that interpersonal relations and trust formation are also key in less knowledge-intensive settings, where more practical types of knowledge are exchanged between a university of applied sciences, and low-tech firms and organisations. Moreover, in our case, the active community-building role of the Knowledge Mile organization helped actors in the street to "discover" their geographical proximity and turn it into an asset for joint activities.

Conceptually, we analysed KM as the intermediary organisation, identifying the three roles of facilitating, configuring, and brokering. This conceptualization from the literature on innovation intermediaries proved very useful in our study, and might be of use for further research on entrepreneurial or engaged universities. The results once more confirm the insight of Agogué et al. (2017) and others that intermediaries are more than middlemen; they are embedded in the co-creation process and play an important role as co-shapers of innovation, influencing in various ways the definition and selection of challenges and research questions, setting of priorities, the direction of solution development, the valuation process, funding, and so on. They are not neutral, but always play their role derived from their own values and preferences for certain options or trajectories. This perspective helps to explain the shifting focus - or mission drift — of KM, as the organisation moved from a purely university-based knowledge intermediary towards the management organisation of the business investment zone.

Finally, this paper points to the lack of understanding of the societal contribution of new kinds of HEI such as AUAS. These HEIs are large and significant players in urban and regional societies in a broad range of domains. Their engagement is shaped by (and embedded in) their practice-oriented research and education strategies, fueled by ambitions to address larger societal problems, and enabled by new types of intermediary structures that are still are poorly understood and documented.

Author Contributions: The paper is written by W.v.W. Interviews have been conducted by I.H., P.v.H. and W.v.W. Figure 1 is created by I.H. Revision process is done by W.v.W., P.v.H. and I.H.

Funding: This research has been made possible by Interreg Europe funding of the Area Based Collective Entrepreneurship in Cities (ABCitiEs) project with grant number PGI05321.

Conflicts of Interest: The authors declare no conflict of interest.

\section{References}

Agogué, Marine, Elsa Berthet, Tobias Fredberg, Pascal Le Masson, Blanche Segrestin, Martin Stoetzel, Martin Wiener, and Anna Yström. 2017. Explicating the role of innovation intermediaries in the "unknown": A contingency approach. Journal of Strategy and Management 10: 19-39. [CrossRef]

Bathelt, Harald, Anders Malmberg, and Peter Maskell. 2004. Clusters and knowledge: Local buzz, global pipelines and the process of knowledge creation. Progress in Human Geography 28: 31-56. [CrossRef] 
Bender, Thomas, ed. 1988. The University and the City. From Medieval Origins to the Present. New York and Oxford: Oxford University Press.

Benneworth, Paul, and Ben Jongbloed. 2013. Policies for Promoting University-Community Engagement in Practice. In University Engagement with Socially Excluded Communities. Edited by Paul Benneworth. Dordrecht: Springer, pp. 243-61.

Benneworth, Paul, and Alan Sanderson. 2009. Building Institutional Capacity for HEI Regional Engagement in a Sparse Innovation Environment: A Case Study of Knowledge House. Paris: OECD iLibrary, Higher Education Management and Policy.

Benneworth, Paul, Rómulo Pinheiro, and Mabel Sanchez-Barrioluengo. 2016. One size does not fit all! New perspectives on the university in the social knowledge economy. Science and Public Policy 43: 731-35. [CrossRef]

Benneworth, Paul, Bojana Ćulum, Thomas Farnell, Frans Kaiser, Marco Seeber, Ninoslav Šćukanec, Hans Vossensteyn, and Don Westerheijden. 2018. Mapping and Critical Synthesis of Current State-of-the-Art on Community Engagement in Higher Education. Zagreb: Institute for the Development of Education.

Bessant, John, and Howard Rush. 1995. Building bridges for innovation: the role of consultants in technology transfer. Research Policy 24: 97-114. [CrossRef]

Boh, Wai F., Uzi De-Haan, and Robert Strom. 2016. University technology transfer through entrepreneurship: faculty and students in spinoffs. The Journal of Technology Transfer 41: 661-69. [CrossRef]

Boltanski, Luc, and Ève Chiapello. 1999. Le Nouvel Esprit du Capitalism. Paris: Gallimard.

Boschma, Ron. 2005. Proximity and innovation: A critical assessment. Regional Studies 39: 61-74. [CrossRef]

Brown, John, and Paul Duguid. 2000. The Social Life of Information. Boston: Harvard Business School Press.

Carvalho, Luis, and Willem van Winden. 2018. Making waves: The valuation of innovations in San Sebastian's surf economy. European Planning Studies 26: 75-93. [CrossRef]

Charles, David. 2006. Universities as key knowledge infrastructures in regional innovation systems. Innovation: The European Journal of Social Science Research 19: 117-30. [CrossRef]

Charles, David. 2011. The Role of Universities in Building Knowledge Cities in Australia. Built Environment 37: 281-98. [CrossRef]

Chatterton, Paul, and John Goddard. 2000. The Response of Higher Education Institutions to Regional Needs. European Journal of Education 35: 475-96. [CrossRef]

Clark, Burton R. 1998. Creating Entrepreneurial Universities: Organizational Pathways of Transformation. Oxford: Pergamon Press.

Clark, Burton. 2004. Delineating the character of the entrepreneurial university. Higher Education Policy 17: 355-70. [CrossRef]

Cooke, Philip. 2001. Regional innovation systems, clusters, and the knowledge economy. Industrial and Corporate Change 10: 945-74. [CrossRef]

Derrick, Gemma E. 2015. Integration versus separation: structure and strategies of the technology transfer office (TTO) in medical research organizations. The Journal of Technology Transfer 40: 105-22. [CrossRef]

Doberneck, Diane M., Chris R. Glass, and John Schweitzer. 2010. From Rhetoric to Reality: A Typology of Publically Engaged Scholarship. Journal of Higher Education Outreach and Engagement 14: 5-31.

Edler, Jakob, and Jillian Yeow. 2016. Connecting demand and supply: The role of intermediation in public procurement of innovation. Research Policy 45: 414-26. [CrossRef]

Evans, James, and Andrew Karvonen. 2014. ‘Give Me a Laboratory and I Will Lower Your Carbon Footprint!' -Urban Laboratories and the Governance of Low-Carbon Futures. International Journal of Urban and Regional Research 38: 413-30. [CrossRef]

Gertler, Mark. 2001. Best practice: geography, learning and the institutional limits to strong convergence. Journal of Economic Geography 1: 5-26. [CrossRef]

Gibbons, Michael, ed. 1994. The New Production of Knowledge: The Dynamics of Science and Research in Contemporary Societies. Newbury Park: Sage Publications Ltd. Available online: https://philpapers.org/rec/GIBTNP (accessed on 24 April 2019).

Goddard, John, and Paul Vallance. 2013. The University and the City. Abingdon: Routledge.

Guston, David H. 1999. Stabilizing the boundary between US politics and science: The role of the Office of Technology Transfer as a boundary organization. Social Studies of Science 29: 87-111. [CrossRef]

Hobbs, Kelsi G., Albert N. Link, and John T. Scott. 2017. Science and technology parks: an annotated and analytical literature review. The Journal of Technology Transfer 42: 957-76. [CrossRef] 
Howells, Jeremy. 2006. Intermediation and the role of intermediaries in innovation. Research Policy 35: 715-28. [CrossRef]

Huguenin, Ariane, and Hugues Jeannerat. 2017. Creating change through pilot and demonstration projects: Towards a valuation policy approach. Research Policy 46: 624-35. [CrossRef]

Ischinger, Barbara, and Jaana Puukka. 2010. Universities for Cities and Regions: Lessons from the OECD Reviews. Change: The Magazine of Higher Learning 41: 8-13. [CrossRef]

Klerkx, Laurens, and Cees Leeuwis. 2009. Establishment and embedding of innovation brokers at different innovation system levels: insights from the Dutch agricultural sector. Technological Forecasting and Social Change 76: 849-60. [CrossRef]

Larédo, Philippe. 2007. Revisiting the Third Mission of Universities: Toward a Renewed Categorization of University Activities? Higher Education Policy 20: 441-56. [CrossRef]

Laursen, Keld, Toke Reichstein, and Ammon Salter. 2011. Exploring the effect of geographical proximity and university quality on university-industry collaboration in the United Kingdom. Regional Studies 45: 507-23. [CrossRef]

Lember, Veiko, Rainer Kattel, and Tarmo Kalvet. 2014. Public procurement and innovation: Theory and practice. In Public Procurement, Innovation and Policy. Edited by Veiko Lember, Rainer Kattel and Tarmo Kalvet. New York: Springer, pp. 13-34.

Lester, Richard K., and Michael J. Piore. 2004. Innovation-The Missing Dimension. Cambridge: Harvard University Press.

Löfsten, Hans, and Peter Lindelöf. 2002. Science Parks and the growth of new technology-based firms-Academic-industry links, innovation and markets. Research Policy 31: 859-76. [CrossRef]

Markman, Gideon D., Phillip H. Phan, David B. Balkin, and Peter T. Gianiodis. 2005. Entrepreneurship and university-based technology transfer. Journal of Business Venturing 20: 241-63. [CrossRef]

Maskell, Peter. 2001. Towards a knowledge-based theory of the geographic cluster. Industrial and Corporate Change 10: 921-43. [CrossRef]

McIlrath, Lorraine, Anne Lyons, and Ronaldo Munck, eds. 2012. Higher Education and Civic Engagement: Comparative Perspectives. London: Palgrave Macmillan.

McMillan, Charles, and Jeffrey Overall. 2016. Management relevance in a business school setting: A research note on an empirical investigation. The International Journal of Management Education 14: 187-97. [CrossRef]

Morgan, Kevin. 2004. The exaggerated death of geography: learning, proximity and territorial innovation systems. Journal of Economic Geography 4: 3-21. [CrossRef]

Nowotny, Helga, Peter B. Scott, and Michael T. Gibbons. 2001. Re-Thinking Science: Knowledge and the Public in an Age of Uncertainty. Hoboken: John Wiley \& Sons. Available online: https://eprints.kingston.ac.uk/1710/ (accessed on 22 November 2019).

Phan, Phillip H., Donald S. Siegel, and Mike Wright. 2005. Science parks and incubators: observations, synthesis and future research. Journal of Business Venturing 20: 165-82. [CrossRef]

Regeer, Barbara R., Renée de Wildt-Liesveld, Barbara van Mierlo, and Joske F. G. Bunders. 2016. Exploring ways to reconcile accountability and learning in the evaluation of niche experiments. Evaluation 22: 6-28. [CrossRef]

Sánchez-Barrioluengo, Mabel, and Paul Benneworth. 2019. Is the entrepreneurial university also regionally engaged? Analysing the influence of university's structural configuration on third mission performance. Technological Forecasting and Social Change 141: 206-18. [CrossRef]

Sandman, Lorilee R. 2008. Conceptualisation of the Scholarship of Engagement in Higher Education: A strategic review, 1996-2006. Journal of Higher Education Outreach and Engagement, North America 12: 91-104.

Stewart, James, and Samsa Hyysalo. 2008. Intermediaries, users and social learning in technological innovation. International Journal of Innovation Management 12: 295-325. [CrossRef]

Storper, Michael, and Allen Scott. 1995. The wealth of regions: market forces and policy imperatives in local and global context. Futures 27: 505-26. [CrossRef]

Storper, Michael, and Anthony J. Venables. 2004. Buzz: face-to-face contact and the urban economy. Journal of Economic Geography 4: 351-70. [CrossRef]

Van de Ven, Andrew, Douglas Polley, Rachud Garud, and Sankaran Venkataraman. 1999. The Innovation Journey. Oxford: Oxford University Press. 
Ward, Kevin. 2006. Policies in motion, urban management and state restructuring: the trans-local expansion of business improvement districts. International Journal of Urban and Regional Research 30: 54-75. [CrossRef] Watson, David, Robert Hollister, Susan E. Stroud, and Elizabeth Babcock. 2011. The Engaged University: International Perspectives on Civic Engagement. New York: Routledge.

(C) 2019 by the authors. Licensee MDPI, Basel, Switzerland. This article is an open access article distributed under the terms and conditions of the Creative Commons Attribution (CC BY) license (http://creativecommons.org/licenses/by/4.0/). 